\title{
Structural Properties of Silica Fume Modified Light Weight Aggregate (Cinder) Concrete
}

\author{
N. Sivalinga rao $^{1}$, V. Bhaskar Desai ${ }^{2}$ and B.L.P.Swamy ${ }^{3}$ \\ ${ }^{I}$ Dy.Exe. Engineer, JNTUA \\ ${ }^{2}$ Professor JNTUA Anantapur, \\ ${ }^{3}$ Professor Vasavi College of Engineering, Hyd.
}

\begin{abstract}
Light weight concrete has become more popular in recent days owing to the tremendous advantages it offers over the conventional concrete but at the same time strong enough to be used for the structural purpose. Lightweight concrete has been successfully used since the ancient Roman times and it has gained its popularity due to its lower density and superior thermal insulation properties. Compared with normal weight concrete, Lightweight concrete can significantly reduce the dead load of structural elements. The most important characteristic of light weight concrete is its low thermal conductivity. This property improves with decreasing density. In the present experimental investigation, cinder, which is an industrial waste from steel manufacturing units, is used as a replacement of conventional aggregate. The conventional mix has been designed for $M_{20}$ grade concrete and is adopted with a water cement ratio 0.50. From the experimental investigations, it is concluded that conventional aggregate replaced with $40 \%$ cinder aggregates by volume and cement is replaced with $10 \%$ silica fume by weight, it is reaches the target mean strength of conventional aggregate concrete. With $100 \%$ cinder aggregate in the normal coarse aggregate and cement replaced with silica fume in weight percentages of $0 \%, 5 \%, 8 \%, 10 \%, 15 \%$ and $20 \%$, compressive strength, split tensile strength, flexural strength , moment carrying, modulus of elasticity and strain energy stored capacity of concrete specimens increase up to $10 \%$ of silicafume and then decrease.
\end{abstract}

Keywords: strain energy, moment carrying, modulus of elasticity

\subsection{Necessity of Light Weight Concrete}

\section{Introduction}

One of the disadvantages of conventional concrete is its high self weight. This heavy self weight of concrete makes it to some extent uneconomical structural material.

\subsection{Design of Light -weight Aggregate Concrete Mix}

Mix design methods applying to normal weight concrete are generally difficult to use with light weight aggregate concrete. The lack of accurate value of absorption, specific gravity, and the free moisture content in the aggregate make it difficult to apply the water/cement ratio accurately for mix proportioning. Light-weight concrete mix design is usually established by trial mixes.

\subsection{Cinder Aggregate:}

Cinder is the material with partly fused or sintered particles arising from the combustion of coal. Pulverized coal is more commonly used as light weight aggregate. It is an industrial waste. The cinder aggregates cannot be really brought under light weight aggregate because the concrete made with this aggregate will not come under the category of light weight aggregate concrete. However since the weight of such concrete will be less than the weight of normal concrete it is included here.

\section{Literature Review}

Takafumi Noguchi, et al., [1] conducted researches on light weight aggregate concrete and suggested a formula for modulus of elasticity. They have arrived at the formula from the test results of different light weight aggregate concrete specimens. The formula is,

$\mathrm{E}=\mathrm{K}_{1} \times \mathrm{K}_{2} \times 1.486 \times 10^{-3} \sigma_{\mathrm{b}}{ }^{1 / 3} \times \gamma^{2}$

Where $\sigma_{\mathrm{b}}=$ Compressive strength in Mpa

$\gamma=$ Density in $\mathrm{Kg} / \mathrm{m}^{3}$ of concrete

$\mathrm{K}_{1}=0.95$ (Correction factor corresponding to coarse aggregates)

$\mathrm{K}_{2}=1.026$ (Correction factor corresponding to mineral admixtures)

Chi JM, et al., [2] also stated that Commercially produced lightweight aggregates were used in concrete by many researchers to investigate the strength, stiffness and durability of concrete. 
Campione, G., et al., [3] reported that the brittle nature of lightweight concrete greatly depends on the aggregates used and in particular on their density: in general, greater aggregate density improves the strength of the material to the detriment of the non-structural properties mentioned above. This disadvantage can be overcome by increasing the ordinary confinement transverse reinforcement and/or by adding reinforcing fibers to the concrete matrix, as has been shown in several recent studies.

Alduaij et al. [4] studied lightweight concrete using different unit weight aggregate including lightweight crushed bricks, lightweight expanded clay and normal weight gravel without the use of natural fine aggregate (no-fines concrete). They obtained a lightweight concrete with $22 \mathrm{MPa}$ cylinder compressive strength and 1520 $\mathrm{kg} / \mathrm{m} 3$ dry unit weight at 28 days.

Wasserman and Bentur [5] had shown that the strength of the concrete could not be accounted for by the strength of the aggregates only and it was suggested that the absorption and pozzolanic activity of the aggregates could have an influence on the strength developed.

4.0. Experimental Investigation: Materials

4.1. Cement: O P C of 43 grade.

4.2. Silica fume: Surface area about $30,000 \mathrm{~m}^{2} / \mathrm{kg}$

4.3. Fine Aggregate: Conformed To Grading Zone-II

4.4. Coarse Aggregate: Conventional Granite

Fully compacted density of coarse aggregate is $1690 \mathrm{~kg} / \mathrm{m}^{3}$

Partially compacted density of coarse aggregate is $1466 \mathrm{~kg} / \mathrm{m}^{3}$

4.5. Light weight aggregate: cinder

Fully compacted density of Lightweight coarse aggregate is $1098 \mathrm{~kg} / \mathrm{m}^{3}$

Loose density of Light weight coarse aggregate is $962 \mathrm{~kg} / \mathrm{m}^{3}$

4.6. Water: Potable water

4.7. Super Plasticizer: SP-430, Fosrac

4.8. Mix Case Considered: $M_{20}$

4.9. Reinforcement details: Beams and Slabs: $8 \mathrm{~mm}$ dia,Fe-415 grade Steel

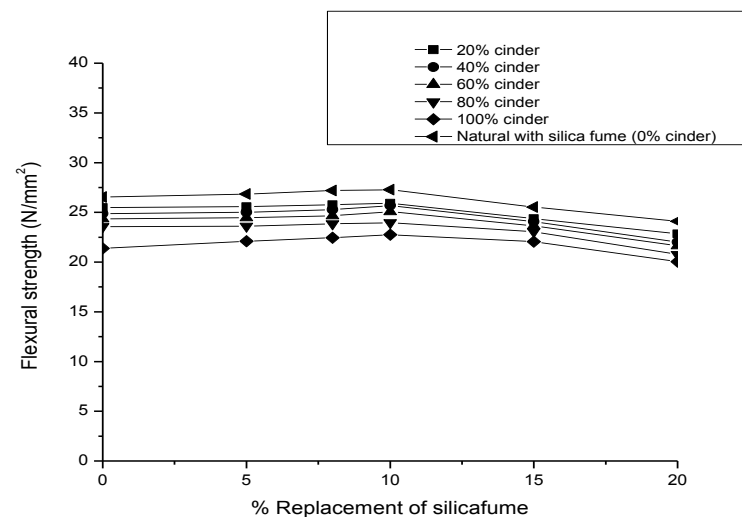

Fig.1.Super imposed variation of Flexural Strength Vs Replacement ofcement by silicafume

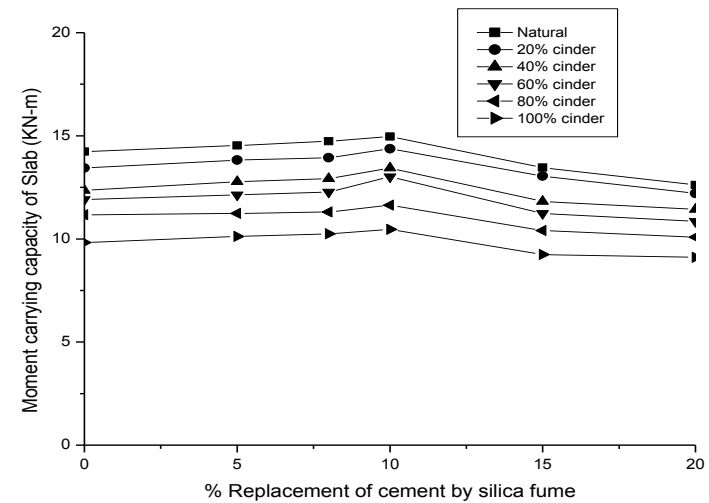

Fig.2.Super imposed variation of Moment carrying capacity of slab Vs Replacement of cement by silica fume 


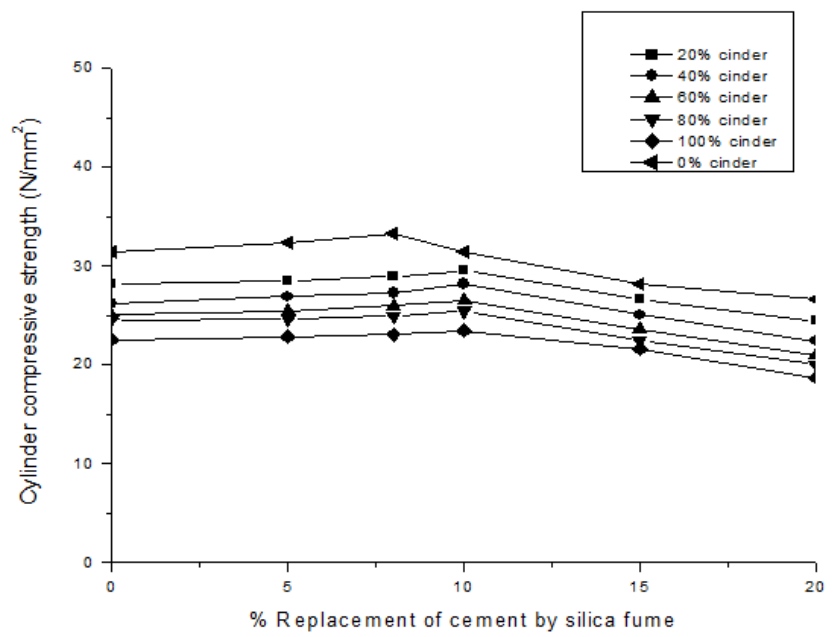

Fig.3.Super imposed variation of Cylinder compressive strength Vs Replacement of Cement by Silicafume

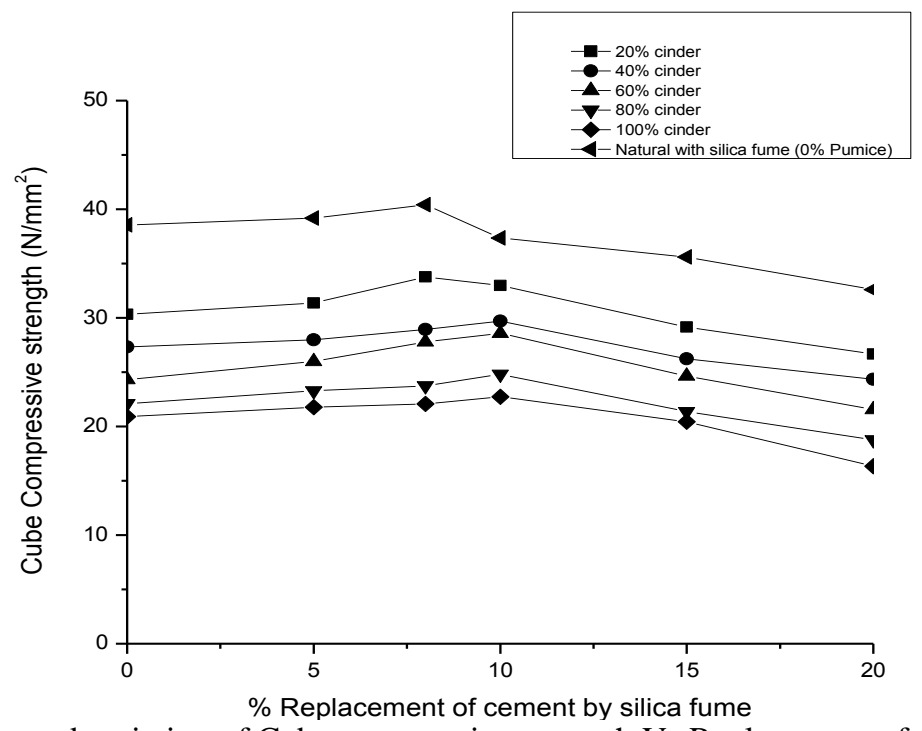

Fig.4.Super imposed variation of Cube compressive strength Vs Replacement of Cement by Silica fume

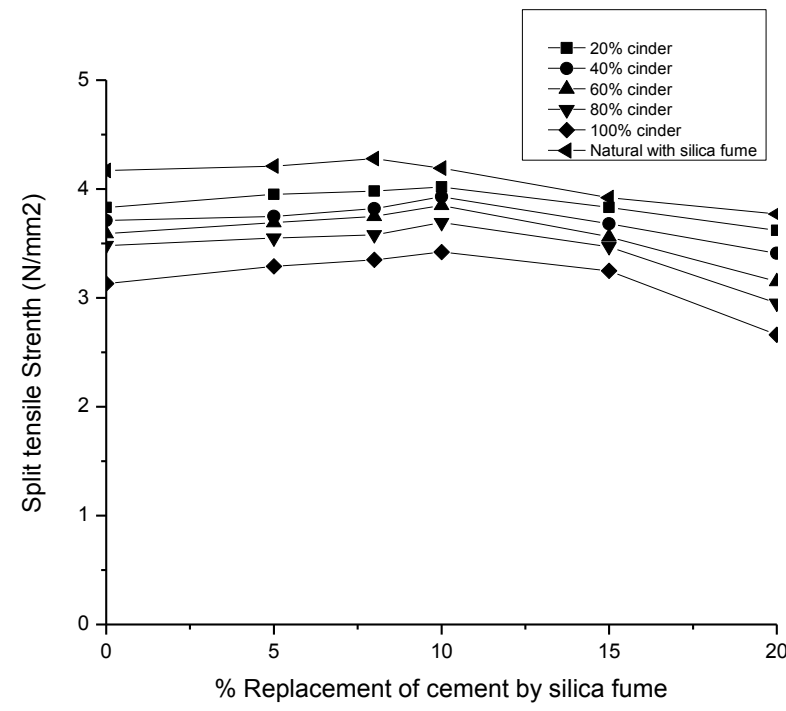

Fig.5. Super imposed variation of Split tensile strength Vs Replacement of Cement by Silicafume 


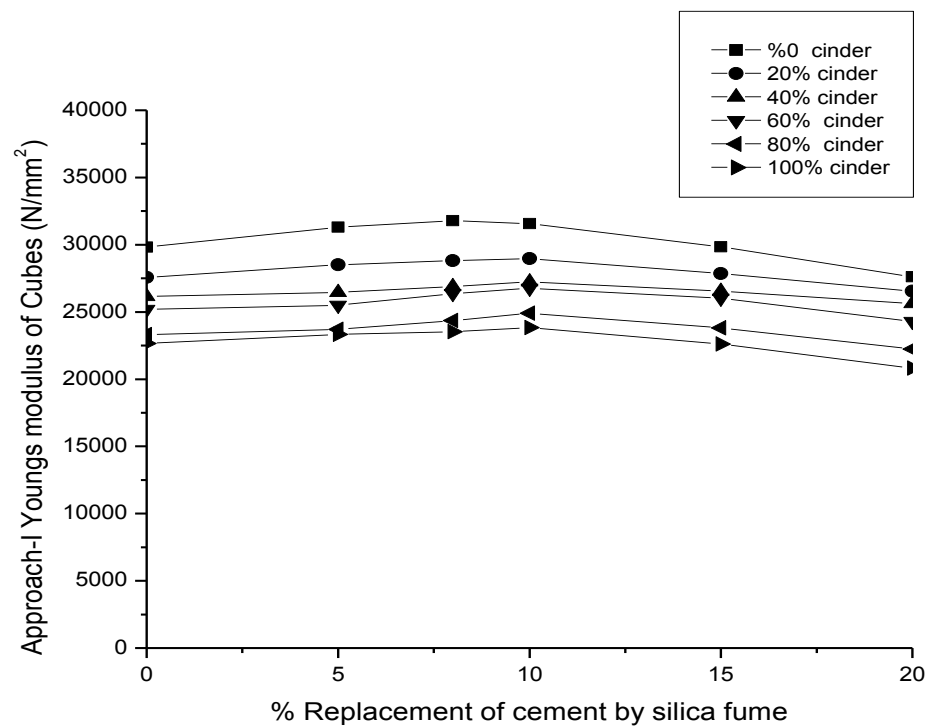

Fig.6. Super imposed variation of Approach-I Youngs Modulus Vs Replacement of cement by silicafume

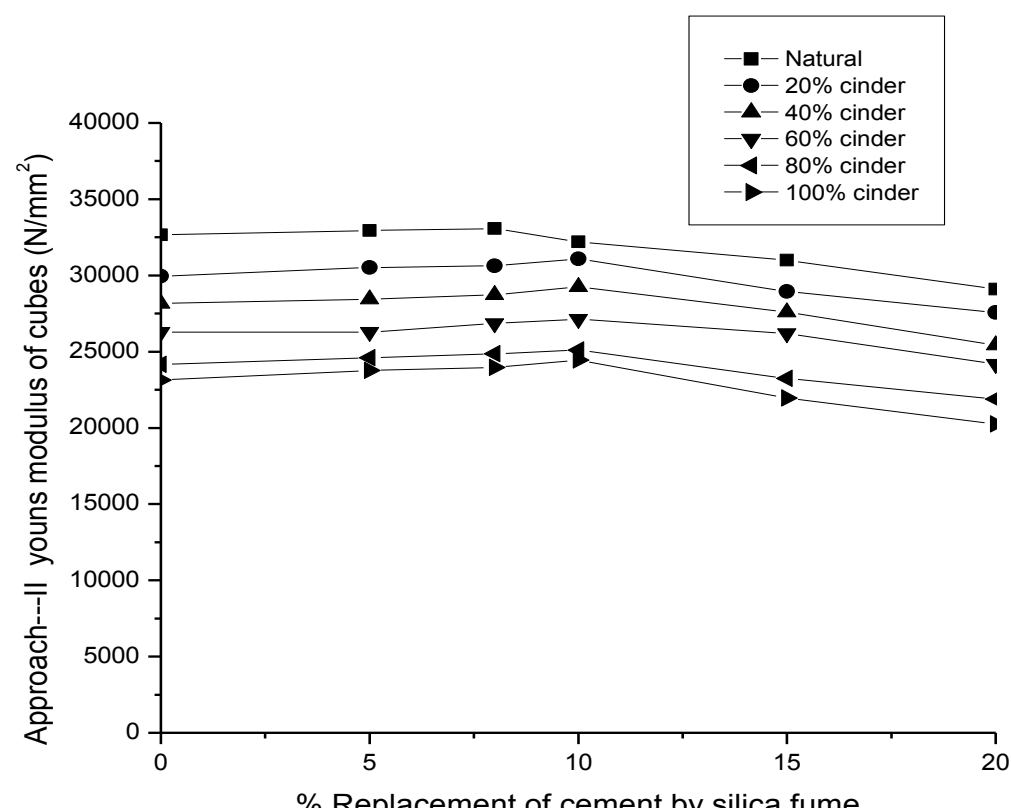

Fig.7. Super imposed variation of Approach-II YoungsModulus Vs Replacement of cement by silicafume

Table.1. Strain Energy Stored In Beams

\begin{tabular}{|c|c|c|c|c|c|}
\hline S No & Id & $\begin{array}{l}\text { Percentage Of } \\
\text { Granite Aggregate }\end{array}$ & $\begin{array}{l}\text { Percentage Of Cinder } \\
\text { Aggregate }\end{array}$ & $\begin{array}{l}\text { Percentage } \\
\text { replacement Of } \\
\text { cement by silicafume }\end{array}$ & $\begin{array}{lc}\text { Strain } & \text { Energy Stored in } \\
\text { Beams } & \left(\mathrm{mm}^{2}\right)\end{array}$ \\
\hline 1 & B3 & 60 & 40 & 10 & 28910.07 \\
\hline 2 & E3 & $\mathbf{0}$ & 100 & 10 & 25870.07 \\
\hline
\end{tabular}

Table.2. Strain Energy Stored In Slabs

\begin{tabular}{|l|l|l|l|l|l|}
\hline S No & Id & $\begin{array}{l}\text { Percentage Of Granite } \\
\text { Aggregate }\end{array}$ & $\begin{array}{l}\text { Percentage Of } \\
\text { Cinder Aggregate } \\
\text { replacement } \\
\text { cement by silicafume }\end{array}$ & $\begin{array}{l}\text { Percentage } \\
\text { Of } \\
\text { in Slabs }\end{array}$ & \\
\hline 1 & $\mathbf{B}_{\mathbf{3}}$ & $\mathbf{6 0}$ & $\mathbf{4 0}$ & & 120483.62 \\
\hline 2 & $\mathbf{E}_{\mathbf{3}}$ & $\mathbf{0}$ & $\mathbf{1 0 0}$ & & 90576.69 \\
\hline
\end{tabular}




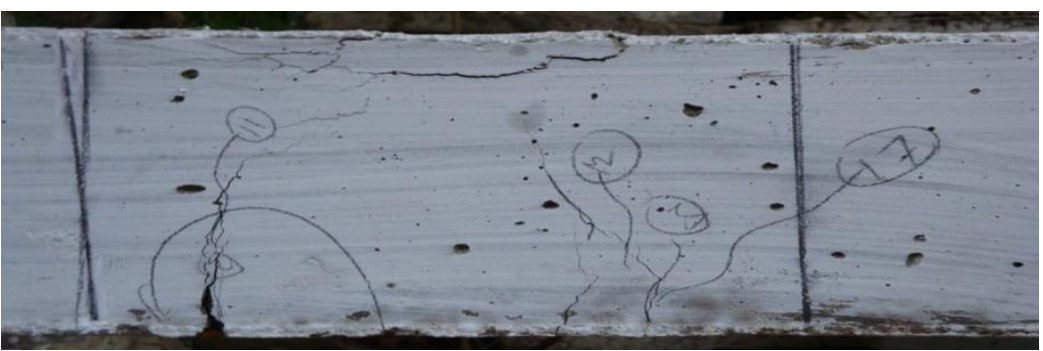

Plate 1. Crack Pattern of Beam

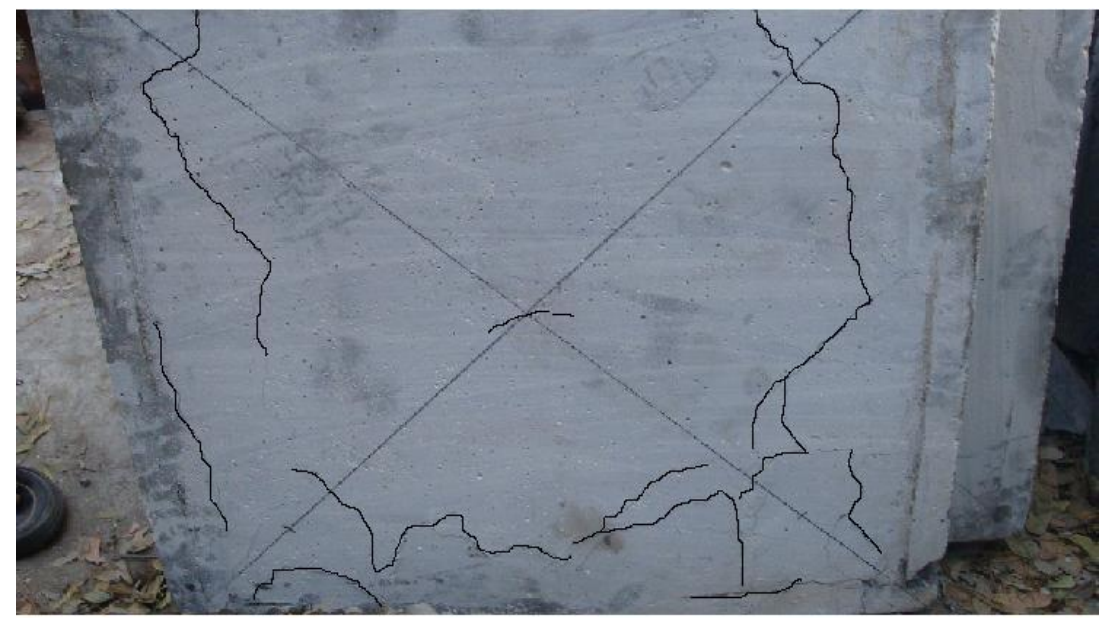

Plate 1. Crack Pattern of slabs

\section{Conclusions}

1. More than the target mean strength of concrete is obtained with 40 percent replacement of conventional aggregate by cinder aggregate and with 10 percent of cement replaced with silica fume. Also the compressive strength of cinder concrete with $60 \%$ cinder content and $10 \%$ silica fume is seen to have achieved a strength more than tangent mean strength of M20 grade concrete.

2. The Young's modulus values of cinder concrete calculated from Approach-I are found to have satisfactory agreement with those calculated by Approach-II up to $20 \%$ replacement of natural aggregate by cinder. The optimum recommended combination for this strength is $40 \%$ cinder and $60 \%$ natural aggregate along with $10 \%$ silica fume.

3. The moment carrying capacity of slabs is found to vary from $14.23 \mathrm{KN}-\mathrm{m}$ to $9.82 \mathrm{KN}-\mathrm{m}$ with the replacement of natural aggregate by cinder from 0 to 100 percent. Between 8 to 10 percent replacement of cement with silicafume gives the optimum values of moment carrying capacity. The optimum recommended combination for this strength is $40 \%$ cinder and $60 \%$ natural aggregate along with $10 \%$ silica fume.

4. With the increase in cinder contents the deflections of beams, slabs etc., are found to increase.

5. Based on the experimental investigations it is concluded that cinder light weight aggregate is no way inferior to other manufactured, developed aggregate like cold bonded, sintered artificial aggregates.

\section{References}

[1] Takafumi Noguchi, Fuminori Tomosawa, Kamran M. Nemati, Bernardino M. Chiaia and Alessandro (2009) A practical Equation for Elastic Modulus of concrete. ACI Structural journal/Sep-Oct 2009, technical paper title no.106-S64.

[2] Chi JM, Huang R, Yang CC, Chang JJ (2003). Effect of aggregate properties on the strength and stiffness of lightweight concrete, Cement Concrete Compos., 25: 197-205.

[3] Campione, G., Mindess, S. and Zingone, G., 'Compressive stress-strain behavior of normal and high-strength carbonfibre concrete reinforced with steel spirals', A CI Materials Journal 96 (1) (1999) 27-34.

[4] J. Alduaij, K. Alshaleh, M.N. Haque, K. Ellaithy, Lightweight concrete in hot coastal areas, Cem. Concr. Compos. 21 (5-6) (1999) 453-458.

[5] R. Wasserman, A. Bentur, Effect of lightweight fly ash aggregate microstructure on the strength of concretes, Cement and Concrete Research 27 (1997) 525-537. 